\title{
Effects of Methionine on the Immune Function in Animals
}

\author{
Tao Ruan1, Lingjun Li1, Xi Peng1,2, Bangyuan $\mathrm{Wu}^{1,2^{*}}$ \\ ${ }^{1}$ College of Life Science, China West Normal University, Nanchong, China \\ ${ }^{2}$ Key Laboratory of Southwest China Wildlife Resources Conservation, Ministry of Education, Nanchong, China \\ Email: ${ }^{*}$ wubangyuan2008@163.com
}

How to cite this paper: Ruan, T., Li, L.J., Peng, X. and Wu, B.Y. (2017) Effects of Methionine on the Immune Function in Animals. Health, 9, 857-869.

https://doi.org/10.4236/health.2017.95061

Received: March 30, 2017

Accepted: May 20, 2017

Published: May 24, 2017

Copyright $\odot 2017$ by authors and Scientific Research Publishing Inc. This work is licensed under the Creative Commons Attribution International License (CC BY 4.0).

http://creativecommons.org/licenses/by/4.0/

\begin{abstract}
Nutrition and immunity are the hot topics in animal's production, and the effects of methionine on the immunity are already confirmed as the deep research on the nutrition of amino acid and immune function. However, the relationship of the methionine and immunity has not been elucidated clearly, this review aims to clarify the effects of methionine on immune function in the aspects of growth and development immune organs, the histological structure of the immune organs, non-specific immunity, humoral immunity, cellular immunity and cytokines, and to provide foundations for further studies on the relationship between methionine and immune function.
\end{abstract}

\section{Keywords}

Methionine, Non-Specific Immunity, Humoral Immunity, Cellular Immunity, Cytokines

\section{Introduction}

As an animal essential amino acid in the daily diet, methionine possesses high nutritional value and important physiological functions [1] [2] [3], such as growth promotion [4] [5], detoxification [6], antitumor and anticancer [7] [8], resistance for coccidium infection [9], involved in methyl transfer [10] [11] [12] and synthesis of protein [13] [14] [15] [16] and so on. What's more, methionine is closely related to the immune function of livestock and poultry, which is not only has effects on the growth and development of immune organs, but also on the specific and nonspecific immune function of organism [17] [18] [19] [20] [21]. In addition, methionine plays a key role in protein synthesis and catabolism of the immune system [22]. On the other hand, the excessive methionine can also cause negative effects on animals, it is suggested that the methionine is the most toxic member of the amino acid family [23] [24] [25] [26]. This review 
aims to discuss the relationship between methionine and animal immune function, and to clarify the mechanism of methionine effects on the immune function ulteriorly.

\section{Effects of Methionine on the Growth and Development of the Immune Organ}

Immune organs mainly include bone marrow, tonsil, lymph nodes, thymus, spleen, and bursa of Fabricius (poultry). It is reported that methionine has different effect on the immune organs. Researches have pointed out that methionine can increase the relative weight of bursa of Fabricius and spleen in chicken [4] [27] [28], but methionine deficiency can lead to immune organs dysplasia [17] [20] [29], and decrease the relative weight of thymus, spleen and bursa of Fabricius [30] [31] [32]. Methionine supply can increase the weight of thymus and bursa of Fabricius of layers in the brood rearing stage, but has no significant effect on the spleen [33]. It is concluded that the development of the primary immune organs (thymus and bursa of Fabricius) may be easily affected than the secondary immune organs (spleen) by methionine [20] [34] [35]. Methionine may also affect the weight of the thymus of the early weaned piglets and meat rabbit [36] (Hou et al., 2001) and increase the head kidney and spleen index in juvenile Jian carp [37].

\section{Effects of Methionine on the Histological Structure of the Immune Organs}

Mehionine deficiency has negative effect on the imuune organs including thymus, bursa of Fabricus and spleen. Research has showed that congestion in cortex and medulla of thymic lobule were observed, and lymphocytes in the medulla was remarkably decreased in number and loosely arranged when methionine deficiency [30]. Lymphocytes were decreased in lymphoid follicles with thinner cortices and wider medullae in the bursa of the methionine-deficient [32]. Methionine deficiency reduced the lymphocytes significantly in white pulp and red pulp, also, the histological structure of spleen was disordered [31]. The swelled or vacuolated mitochondria of lymphocytes and more apoptotic lymphocytes were ultrastructurally observed in the spleens with methionine deficiency treatment in broilers [30] [31] [32].

\section{Effects of Methionine on Nonspecific Immune Function}

There are few researches about the effects of methionine on nonspecific immune function. Some studies showed that methionine can enhance the phagocytic activity of the leukocyte [21] [38], peripheral blood lymphocyte activity, and serum lysozyme activity [39] [40]. Methionine deficiency at the period of pregnancy or lactation will decrease the capacity of the spleen lymphocytes to the same or alloantigen nonspecific immunostimulatory [41]. We speculated that methionine may be an essential substance which maintained the nonspecific immune function. 


\section{Effects of Methionine on Specific Immune Function}

\subsection{Effects of Methionine on Humoral Immunity}

Humoral immunity is mainly reflected by the recognition of B lymphocytes to antigen, and then the B lymphocytes proliferation or differentiation into plasma cells and secretion of specific antibodies. Methionine affects animals humoral immune function mainly displays in its effects on the body antibody titer and level of immunoglobulins. The appropriately methionine level can significantly increase the degree of antibody [4] [42] [43] and the sheep red blood cells antibody titer [44]. With the level of methionine increasing in the daily diet, the serum antibody increases in the broilers which infected by coccidium [45], and the leukocyte migration and antibody titer also increased in chicken which infected by Newcastle disease virus [18] [46]. However, methionine deficiency will inhibit the proliferation and differentiation of bursal lymphocytes (mainly B lymphocytes), and increase the percentage of the apoptotic cells [32].

Immunoglobulin A ( $\operatorname{Ig} A)$, immunoglobulin $G(\operatorname{IgG})$, immunoglobulin $M$ ( $\operatorname{IgM})$, immunoglobulin D ( $\operatorname{IgD})$, immunoglobulin $\mathrm{E}(\operatorname{IgE})$ are the mainly immunoglobulin subtypes in animals. Methionine can affect humoral immune function by the immunoglobulin levels. Dietary methionine has significant influence on the content of serum IgM and IgA of 2-month New Zealand meat rabbit [47]. Another study points out that methionine has positive effects on the IgG levels of the blood in weaning piglets [36]. Wu et al. (2012a) [30] reported that methionine deficiency can decrease serum IgG, IgA and IgM content significantly, which suggests that the humoral immune function is injured. In addition, the level of the methionine is higher in the immune response than normal condition [48] [49] [50], which suggesting that it has close relationship between the methionine and immune response or disease resistance. Increase the dose of methionine in the diet of chicken which infected by Newcastle disease virus, the level of IgG increased too [51]. Methionine also has a protective role in the toxicological effect of aflatoxin [52]. Studies also point out that methionine can promote young carp intestinal humoral immune function by affecting the activity of lysozyme, hemagglutination titer, total iron binding capacity, complement 3 (C3) or complement 4 (C4) content and the IgM content [53].

\subsection{Effects of Methionine on Cellular Immunity}

Animal cellular immunity is mainly achieved by differentiation of cytotoxic $\mathrm{T}$ lymphocytes and producing of the cytokines which activated by antigen of the $\mathrm{T}$ lymphocytes. At the same time, the cellular immunity refers to the phagocytosis of macrophage, cell-mediated cytotoxic effect of the killer (K) cells and natural killer (NK) cells. Diets supplemented with digestible methionine could improve the cellular immune response of broiler chicks [54] [55]. Methionine can promote $\mathrm{T}$ lymphocyte proliferation ability of the peripheral blood, thymus and spleen, and methionine deficiency will reduce the transformation of $\mathrm{T}$ lymphocyte proliferation ability [56] [57]. Research shows that the methionine can 
promote the thymus $\mathrm{T}$ lymphocyte cells differentiation which induced by phytohaemagglutinin (PHA) and enhance the cellular immune function [45]. Wu et al. (2012a) found that methionine deficiency can affect the relative percentage of $\mathrm{T}$ lymphocyte subsets $\left(\mathrm{CD}^{+}\right.$and $\mathrm{CD} 3^{+} \mathrm{CD}^{+}$and $\left.\mathrm{CD} 3^{+} \mathrm{CD} 4^{+}\right)$of chicken broilers [30]. The superoxide dismutase (SOD) and glutathione peroxidase (GSH-Px) activities, and abilities to inhibit hydroxyl radicals were greatly decreased while the malondialdehyde (MDA) contents were markedly increased when methionine deficiency [31], and it shows that methionine deficiency can induced oxidative damage and lipid peroxidation, which leads to the accumulation of free radicals and eventually injure the biofilm structure of lymphocytes and finally affects the cellular immunity.

Methionine deficiency will reduce PHA reactivity, reduce the stimulus reaction of spleen lymphocytes to concanamycin A (ConA) and mitogenesis of thymic cells. Researcher also points out that methionine deficiency can decrease the PHA reactivity of animal [9], but after supplement of methionine, the lymphocyte transformation reaction enhanced in different degree [58], which can also significantly increase the reaction of peripheral blood lymphocytes to ConA and proliferation of conversion rate which induced by PHA [59].

\subsection{Effects of Methionine on Cytokines}

There are few reports about the methionine on cytokines in animals. The generation of the Interleukin 1 (IL-1), interleukin 6 (IL-6) and tumor necrosis factor (TNF) has closely relationship to the metabolism of sulfur-containing amino acids including methionine [60] [61] [62]. Methionine is a necessary factor for the generation of IL-1 [63]. Though the research about how methionine directly affect the interleukin 2 (IL-2) is uncommon, some studies reported that methionine may affect peripheral blood IL-2 through the pathways of provision of thiol and promotion of lymphcytes division [64]. Wu (2012) have found that methionine deficiency can significantly reduce the content of serum IL-2 in chicken broilers [30].

\section{The Mechanism of the Effect of Methionine on Immune Function}

The mechanism of effect of methionine on the immune response has not been fully elucidated, here we speculate that some possible mechanisms may be involved: methionine can be act as immune regulatory factor, such as IL-1 [65] or hormone (insulin-like growth factor-I, triiodothyronine and thyroxine) [66] [67] can be regulated by the methionine; Methionine as a donor of methyl groups, and it participates in the methylation of DNA and proteins, involving in the synthesis of spermine and spermine, and thereby regulate immune related genes expression [68]. Methionine also can indirect regulate the lymphocytes proliferation and differentiation by polyamine [69]. Methionine is the substrate of the synthesis of choline, therefore, phosphatidyl choline and acetylcholine play key roles in the metabolism of leukocyte [6]. As a glutathione precursor amino acids, 
methionine can protect cells from oxidative damage [70] [71] [72] [73], which may be play important role in the effect of methionine on immune organs or function.

\section{Methionine and Cancer}

It is reported that many cancers or tumors has closed relationship with the methionine. In animals, methionine restriction may impair cancer growth and carcinogenesis. The requirement for methionine is a common feature of some cancers, which is known as "methionine dependence" [74]. Thus, the restriction of methionine may be a useful strategy in limiting cancer cellular growth. Dietary restriction of methionine in combination with other nutrients that are known to aid cancer growth may have an additive effect in limiting growth and metastases of cancers [75]. Therefore, methionine requirements may be more elevated in cancer cell, because of increased protein synthesis and an increase of transmethylation reactions [76]. Dietary methionine restriction may also extend lifespan. In mice, a methionine-deficient diet prolongs life-span and slows immune system [77].

\section{The Metabolism of Methionine Pathways}

Methionineis partitioned between protein synthesis and the de novo pathway in every cell, which also referred to as the methylation cycle or recycling pathway where it is converted to S-adenosylmethionine (SAM), the principal methyl donor [78] under the influence of methionine adenosyltransferase [79]. In the process of methylation, SAM is converted to S-adenosyl-homocysteine and a large range of proteins and other molecules [80] in the presence of methyltransferases. Homocysteine, biosynthesized from methionine, can condense with serine to form cystathionine [11] [81]. Both powder and liquid forms consist of an L-isomer and a D-isomer at a ratio of 1:1. In the metabolic pathway of poultry, $70 \%-100 \%$ of the D-isomer of DLM or LMA is converted to L-isomer [82] [83] [84] [85] and utilized by the body.

\section{Source of Methionine}

Many foods contain high level of methionine, such as milk, meat, seeds, peanut, soybean, rice, wheat, sweet basket, broccoli, chives, garlic, watercress, pineapple, apple and so on. But in the breeding industry, the level of the methionine in the feed can't meet the need of the animals, it needs to be added by artificial. As a feed additive, the DL-methionine (DLM) is produced from a complex chemical synthetic process, and the starting material for its production is acrolein derived from propylene [86]. Industrially, the powder and liquid forms of methionine sources are mainly used. It is known as DLM (powder form) and DL-2-hydroxy4-[methyl] butanoic acid (LMA: liquid form).

\section{Other Uses of Methionine}

Methionine is not only used as the feed additives in the poultry, but also widely 
used in some other aspects. In the medical industry, methionine can be clinically used for the prevention and treatment for the chronic hepatitis, cirrhosis, fatty liver disease, or cholestatic liver disease [87], and adjuvant therapy for the poisoning of the sulfa drugs, arsenic or benzene [88] [89] [90]. In addition, methionine also can be used as a cholagogue medicine, adjusting the $\mathrm{pH}$ of urine, reducing adipose accumulation [91], and methionine is an important composition of the medical amino acid infusion. In the medical cosmetic, methionine can promote formation of skin collagen and keratin protein, promote growth hormone secretion and skin healthy [92] [93]. Methionine is also a kind of antioxidant, sulfur atomic in methionine molecule can scavenge free radicals. In addition, methionine has a wide application in the field of foods, biochemical research, photography and so on [94] [95] [96].

\section{Perspectives}

\subsection{Research Contents Should Be Diversified}

At present, the research on the immune system of methionine mainly focuses on the immune organ weight, growth index, the production of some antibodies and lymphocyte proliferation. However, very few studies focus on the morphological pathology or genes changes of the immune system or immune organs which are induced by methionine deficiency, so more work needs us to do.

\subsection{The Mechanism of the Effect of Methionine on Immune System Needs to Be Further Studied}

The mechanism of the effect of methionine on immune function is still in the preliminary phase, and the mechanism is not clear reported, which needs to be studied further. Meanwhile, the molecular level or methods should be used to clarify the mechanism, such as cell culture in vitro should be used to study the mechanism.

\subsection{Research Methods Should Be Diversified}

At present, traditional ways are mainly used to study the effects of methionine on immune system, such as organ weight, the determination of blood biochemical index and some enzyme activities by some certain kits, and a variety of new technologies should be used in the research. All above questions that remain are challenging and will require the innovation of new tools and approaches. It is necessary to draw lessons from new technology in human medical research, and promote the research development of the methionine effect on the immune system in the direction of standardization and accuracy, such as introduction of immune histochemical staining, cell culture techniques or flow cytometry assay method, next-generation sequencing technology and so on.

\section{Acknowledgements}

The study was supported by the program for the scientific research project of 
China West Normal University (416370).

\section{References}

[1] Avila, M.A., Berasain, C., Torres, L., Martín-Duce, A., Corrales, F.J., Yang, H., Prieto, J., Lu, S.C., Caballeria, J., Rodes, J. and Mato, J.M. (2000) Reduced Mrna Abundance of the Main Enzymes Involved in Methionine Metabolism in Human Liver Cirrhosis and Hepatocellular Carcinoma. Journal of Hepatology, 33, 907-914.

[2] Yang, L.J., Huo, Z.C., Hou, J.C., Cheng, P. and Sun, S.L. (2004) The Comparison of the Effect of the Solid Methionine and Liquid Methionine on the Chicken Biological Titer. Chinese Journal of Animal Science, 40, 16-18.

[3] Oz, H.S., Chen, T.S. and Neuman, M. (2008) Methionine Deficiency and Hepatic Injury in a Dietary Steatohepatitis Model. Digestive Diseases and Sciences, 53, 767776. https://doi.org/10.1007/s10620-007-9900-7

[4] Mirzaaghatabar, F., Saki, A.A., Zamani, P., Aliarabi, H. and Hemati Matin, H.R. (2011) Effect of Different Levels of Diet Methionine and Metabolisable Energy on Broiler Performance and Immune System. Food and Agricultural Immunology, 22, 93-103. https://doi.org/10.1080/09540105.2010.530249

[5] Yen, C.L., Mar, M.H., Craciunescu, C.N., Edwards, L.J. and Zeisel, S.H. (2002) Deficiency in Methionine, Tryptophan, Isoleucine, or Choline Induces Apoptosis in Cultured Cells. Journal of Nutrition, 132, 1840-1847.

[6] Kim, W.K., Froelich, C.A., Patterson, P.H. and Ricke, S.C. (2006) The Potential to Reduce Poultry Nitrogen Emissions with Dietary Methionine or Methionine Analogues Supplementation. World Poultry Science Journal, 62, 338-353. https://doi.org/10.1079/WPS2005103

[7] Horvat, S., Mlinaric-Majerski, K., Glavas-Obrovac, L., Jakas, A., Veljkovic, J., Marczi, S., Kragol, G., Roscic, M., Matkovic, M. and Milostic-Srb, A. (2006) Tumor-CellTargeted Methionine-Enkephalin Analogues Containing Unnatural Amino acids: Design, Synthesis, and in Vitro Antitumor Activity. Journal of Medicinal Chemistry, 49, 3136-3142. https://doi.org/10.1021/jm051026+

[8] Li, C., Li, Z., Sletten, E., Arnesano, F., Losacco, M., Natile, G. and Liu, Y. (2009) Methionine Can Favor DNA Platination by Trans-Coordinated Platinum Antitumor Drugs. Angewandte Chemie International Edition, 48, 8497-8500. https://doi.org/10.1002/anie.200902948

[9] Rama Rao, S.V., Prahara, J.N.K., Panda, A.K. and Reddy, M.R. (2003) Interaction between Genotype and Dietary Concentrations of Methionine for Immune Function in Commercial Broilers. British Poultry Science, 44, 104-112. https://doi.org/10.1080/0007166031000085283

[10] Sanchez-Roman, I., Gomez, A., Gomez, J., Suarez, H., Sanchez, C., Naudi, A., Ayala, V., Portero-Otin, M., Lopez-Torres, M., Pamplona, R. and Barja, G. (2011) Forty Percent Methionine Restriction Lowers DNA Methylation, Complex I ROS Generation, and Oxidative Damage to mtDNA and Mitochondrial Proteins in Rat Heart. Journal of Bioenergetics and Biomembranes, 43, 699-708. https://doi.org/10.1007/s10863-011-9389-9

[11] Waterland, R.A. (2006) Assessing the Effects of High Methionine Intake on DNA Methylation. Journal of Nutrition, 136, 1706S-1710S.

[12] Stadtman, E.R., Moskovitz, J., Berlett, B.S. and Levine, R.L. (2002) Cyclic Oxidation and Reduction of Protein Methionine Residues Is an Important Antioxidant Mechanism. Molecular and Cellular Biochemistry, 234, 3-9.

https://doi.org/10.1023/A:1015916831583 
[13] Waterlow, J.C., Tomkins, A. and Grantham-McGregor, S.M. (1992) Protein Energy Malnutrition. India, 1991, 59-86.

[14] Tesseraud, S., Everaert, N., Ezzine, S.B., Collin, A. and Berri, S.M.C. (2011) Manipulating Tissue Metabolism by Amino Acids. World Poultry Science Journal, 67, 243-252. https://doi.org/10.1017/S0043933911000274

[15] Brosnan, J.T. and Brosnan, M.E. (2006) The Sulfur-Containing Amino Acids: An Overview. Journal of Nutrition, 136, 1636S-1640S.

[16] Li, G.W., Burkhardt, D., Gross, C. and Weissman, J.S. (2014) Quantifying Absolute Protein Synthesis Rates Reveals Principles Underlying Allocation of Cellular Resources. Cell, 157, 624-635.

[17] Zhang, L.B. and Guo, Y.M. (2008) Effects of Liquid DL-Methionine Hydroxy Analogue on Growth Performance and Immune Responses in Broiler Chickens. Chinese Journal of Animal Veterinary Science, 9, 1204-1211.

[18] Swain, B.K. and Johri, T.S. (2000) Effect of Supplemental Methionine, Choline and Their Combinations on the Performance and Immune Response of Broilers. British Poultry Science, 41, 83-88. https://doi.org/10.1080/00071660086457

[19] Guerrero, J.M. and Reiter, R.J. (2002) Melatonin-Immune System Relationships. Current Topics in Medicinal Chemistry, 2, 167-179. https://doi.org/10.2174/1568026023394335

[20] Konashi, S., Takahashi, K. and Akiba, Y. (2000) Effects of Dietary Essential Amino Acid Deficiencies on Immunological Variables in Broiler Chickens. British Journal of Nutrition, 83, 449-456.

[21] Elmada, C.Z., Huang, W., Jin, M., Liang, X., Mai, K. and Zhou, Q. (2016) The Effect of Dietary Methionine on Growth, Antioxidant Capacity, Innate Immune Response and Disease Resistance of Juvenile Yellow Catfish (Pelteobagrus fulvidraco). Aquaculture Nutrition, 22, 1163-1173. https://doi.org/10.1111/anu.12363

[22] Grimble, R.F. (2006) The Effects of Sulfur Amino Acid Intake on Immune Function in Humans. British Journal of Nutrition, 136, 1660S-1665S.

[23] Duan, J.L., Li, Y., Wang, Y.C., Pan, Z.H., Gao, X.W., Pan, Y.Y., Fang, G.Q. and Toyoaki, M. (2003) Hyperhomocysteinemia after an Oral Methionine Load Impairs Angiogenesis in Response to Hindlimb Ischemia. Chinese Journal of Arteriosclerosis, 11, 493-497.

[24] Selhub, J. and Troen, A.M. (2016) Sulfur Amino Acids and Atherosclerosis: A Role for Excess Dietary Methionine. Annals of the New York Academy of Sciences, 1363, 18-25. https://doi.org/10.1111/nyas.12962

[25] Kim, S.Y., Kim, H. and Min, H. (2015) Effects of Excessive Dietary Methionine on Oxidative Stress and Dyslipidemia in Chronic Ethanol-Treated Rats. Nutrition Research and Practice, 9, 144-149. https://doi.org/10.4162/nrp.2015.9.2.144

[26] Chaturvedi, P., Kamat, P.K., Kalani, A., Familtseva, A. and Tyagi, S.C. (2016) High Methionine Diet Poses Cardiac Threat: A Molecular Insight. Journal of Cellular Physiology, 231, 1554-1561. https://doi.org/10.1002/jcp.25247

[27] Pan, F.Y., Feng, L., Jiang, W.D., Jiang, J., Wu, P., Kuang, S.Y., Tang, L., Tang, W.N., Zhang, Y.A., Zhou, X.Q. and Liu, Y. (2016) Methionine Hydroxy Analogue Enhanced Fish Immunity via Modulation of NF- $\kappa$ B, TOR, MLCK, MAPKs and Nrf2 Signaling in Young Grass Carp (Ctenopharyngodon idella). Fish \& Shellfish Immunology, 56, 208-228.

[28] Al-Mayah, A.A. (2006) Immune Response of Broiler Chicks to DL-Methionine Supplementation at Different Ages. International Journal of Poultry Science, 5, 169172. https://doi.org/10.3923/ijps.2006.169.172 
[29] Zheng, H., Li, B., Fan, W. and Zhang, D.Y. (2008) Effect of Two Kinds of Methionine Additives on the Production Performance and Development of Immune Organs in Broiler Chickens. Feed China, 2008, 25-27.

[30] Wu, B., Cui, H., Peng, X., Fang, J. and Liu, X.D. (2012a) Effect of Methionine Deficiency on the Thymus and the Subsets and Proliferation of Peripheral Blood T-Cell, and Serum IL-2 Contents in Broilers. Journal of Integrative Agriculture, 11, 10091019.

[31] Wu, B., Cui, H., Peng, X., Fang, J. and Liu, X.D. (2012b) Pathology of Spleen in Chickens Fed on a Diet Deficient in Methionine. Health, 4, 32-38. https://doi.org/10.4236/health.2012.41007

[32] Wu, B., Cui, H., Peng, X., Fang, J., Cui, W. and Liu, X.D. (2013) Pathology of Bursae of Fabricius in Methionine-Deficient Broiler Chickens. Nutrients, 5, 877-886. https://doi.org/10.3390/nu5030877

[33] Deng, K., Wonga, C.W. and Nolana, J.V. (2007) Carry-Over Effects of Early-Life Supplementary Methionine on Lymphoid Organs and Immune Responses in EggLaying Strain Chickens. Animal Feed Science and Technology, 134, 66-76.

[34] Deng, K., Wong, C.W. and Nolan, J.V. (2006) Long-Term Effects of Early-Life Dietary L-Carnitine on Lymphoid Organs and Immune Responses in Leghorn-Type Chickens. Journal of Animal Physiology and Animal Nutrition, 90, 81-86. https://doi.org/10.1111/j.1439-0396.2005.00569.x

[35] Sahu, T., Tiwari, S.P. and Naik, S.K. (2014a) Effect of Taurine and Methionine on Lymphoid Organs of Vencobb Broilers.

[36] Hou, Y.Q., Guo, Y.M., Zhou, Y.P., Ji, C. and Zhao, J.Y. (2001) Effects of Different Dietary Levels of Protein, Lysine, Methionine and Threonine on Immune Function in Early-Weaned Pglets. Chinese Journal of Animal Science, 37, 18-20.

[37] Kuang, S.Y., Xiao, W.W., Feng, L., Liu, Y., Jiang, J., Jiang, W.D., Hu, K., Li, S.H., Tang, L. and Zhou, X.Q. (2012) Effects of Graded Levels of Dietary Methionine Hydroxy Analogue on Immune Response and Antioxidant Status of Immune Organs in Juvenile Jian Carp (Cyprinus carpio var. Jian). Fish \& Shellfish Immunolo$g y, 32,629-636$.

[38] Shuai, K. and Zhou, X.Q. (2006) Effects of Methionine on Young Carp Digestion Function and Immune Function. Research on Animal Nutrition and Feed, the Fifth National Academic Symposium on Feed Nutrition.

[39] Chen, N.S., Ma, J.Z., Zhou, H.Y., Zhou, J., Qiu, X.J., Jin, L.N. andLin, L.F. (2010) Assessment of Dietary Methionine Requirement in Largemouth Bass, Micropterus Salmoides. Journal Fisheries China, 34, 1244-1253. https://doi.org/10.3724/SP.J.1231.2010.06865

[40] Zhang, L.B. and Wo, Y.M. (2008) Effects of Liquid DL2Methionine Hydroxy Analogue on Growth Performance and Immune Responses in Broiler Chickens. Acta Veterinaria et Zootechnica Sinica, 39, 1204-1211.

[41] Wolliams, E.A., Gebhardt, B.M., Morton, B. and Newberne P.M. (1979) Effects of Early Marginal Methionine-Choline Deprivation on the Development of the Immune System in the Rat. Clinical Nutrition, 32, 1214-1223.

[42] Takahashi, K., Konashi, S., Akiba, Y. and Horiguchi, M. (1993) Effects of Marginal Excess or Deficiency of Dietary Methionine on Antibody Production in Growing Broilers. Animal Science and Technology, 64, 13-19.

[43] Takahashi, K., Konashi, S., Akiba, Y. and Horiguchi, M. (1994) Effects of Dietary Threonine Level on Antibody Production in Growing Broilers. Animal Science and Technology, 65, 956-960. https://doi.org/10.2508/chikusan.65.956 
[44] Sun, C.Y., Shuai, K., Feng, L., Liu, Y. and Zhou, X.Q. (2009) Effects of Methionine on Immune Response and Disease Resistance of Juvenile Jian Carp (Cyprinus carpio var. Jian). Chinese Journal of Animal Nutrition, 21, 506-512.

[45] Jin, L.M., Wang, M., Meng, X.Y., Zhao, Z.X. and Zhao, Q.P. (2005) Effect of Content of Dietary Methionine on the Value of Blood Sugar of Broiler Chikens with E.tenella. Acta Ecologiae Animalis Domastici, 26, 61-64.

[46] Bouyeh, M. (2012) Effect of Excess Lysine and Methionine on Immune System and Performance of Broilers. Annals of Biological Research, 3, 3218-3224.

[47] Zhang, Y.C. and Li, F.C. (2008) Effect of Dietary Methionine Supplement Levels on Growth Performance, Immunity Performance and Blood Metabolites of 2-3 Month-Old Rabbits. Southwest China Journal of Agricultural Sciences, 1, 472-475.

[48] Koga, T., Claycombe, K. and Meydani, M. (2012) Homocysteine Increases Monocyte and T-Cell Adhesion to Human Aortic Endothelial Cells. Atherosclerosis, 161, 365-374.

[49] Eduardo, G.A., Gisele, C.F., Daniela, C., Fabiana, G. and Jose, C.D. (2009) The Effect of Lysine and Methionine in Poultry and Fish Diets. Journal of the Arabian Aquaculture Society, 295, 266-270.

[50] Rubin, L.L., Ribeiro, A.L.M., Canal, C.W., Silva, I.C., Trevizan, L., Vogt, L.K., Pereira, R.A. and Lacerda, L. (2007) Influence of Sulfur Amino Acid Levels in Diets of Broiler Chickens Submitted to Immune Stress. Revista Brasileira de Ciência Avícola, 9, 305-311. https://doi.org/10.1590/s1516-635x2007000100008

[51] Tsiagbe, V.K., Cook, M.E., Harper, A.E. and Sunde, M.L. (1987) Enhanced Immune Responses in Broiler Chicks Fed Methionine-Supplemented Diets. Poultry Science, 66, 1138-1146. https://doi.org/10.3382/ps.0661138

[52] Van, H.E., Spears, J.W., Coffey, M.T., Kegley, E.B. and Qureshi, M.A. (1994) The Effect of Methionine and Aflatoxin on Immune Function in Weanling Pigs. Journal of Animal Science, 72, 658-664.

[53] Tang, L., Wang, G.X., Jiang, J., Feng, L., Yang, L., Li, S.H., Kuang, S.Y. and Zhou, X.Q. (2009) Effect of Methionine on Intestinal Enzymes Activities, Microflora and Humoral Immune of Juvenile Jian Carp (Cyprinus carpio var. Jian). Aquaculture Nutrition, 15, 477-483. https://doi.org/10.1111/j.1365-2095.2008.00613.x

[54] Shini, S., Li, X. and Bryden, W.L. (2005) Methionine Requirement and Cell-Mediated Immunity in Chicks. Asia Pacific Journal of Clinical Nutrition, 14, S123-S123.

[55] Sahu, T., Tiwari, S.P. and Naik, S.K. (2014b) Taurine and Methionine on Immune Response of Broiler Chickens. Indian Veterinary Journal, 91, 33-36.

[56] Kinscherf, R., Fischbach, T., Mihm, S., Roth, S., Hohenhaus-Sievert, E., Weiss, C., Edler, L., Bartsch, P. and Droge, W. (1994) Effect of Glutathione Depletion and Oral N-Acetyl-Cysteine Treatment on CD4+ and CD8+ Cells. The FASEB Journal, 8, 448-451.

[57] Shen, Z.M. and Xie, H.M. (2004) Effects of Cysteamine Hydrochloride and Methionine Lysine on Cellular Immune of Goats. Chinese Journal of Veterinary Science and Technology, 34, 27-32.

[58] Ma, X.C., Gan, Z.W., Feng, B. and Chen, Q.L. (1997) Effects of Vitanins and Methionine on the Cell Mediated Immunity of Silicosis Murine. Acta Nutrimenta Sinica, 19, 224-228.

[59] Soder, K.J. and Holden, L.A. (1999) Lymphocyte Proliferation Response of Lactating Dairy Cows Fed Varying Concentrations of Rumen-Protected Methionine. Journal of Dairy Science, 82, 1935-1942. 
https://doi.org/10.3168/jds.S0022-0302(99)75429-9

[60] Katz, Y., Nadiv, O. and Beer, Y. (2001) Interleukin-17 Enhances Tumor Necrosis Factor $\alpha$-Induced Synthesis of Interleukins 1, 6, and 8 in Skin and Synovial Fibroblasts: A Possible Role as a "Fine-Tuning Cytokine" in Inflammation Processes. Arthritis \& Rheumatism, 44, 2176-2184. https://doi.org/10.1002/1529-0131(200109)44:9<2176::AID-ART371>3.0.CO;2-4

[61] Hong, C.Y., Jin, H.P., Ahn, R.S., Im, S.Y., Choi, H.S., Soh, J., Mellon, S.H. and Lee, K. (2004) Molecular Mechanism of Suppression of Testicular Steroidogenesis by Proinflammatory Cytokine Tumor Necrosis Factor Alpha. Molecular and Cellular Biology, 24, 2593-2604. https://doi.org/10.1128/MCB.24.7.2593-2604.2004

[62] Klasing, K.C., Laurin, D.E., Peng, R.K. and Fry, D.M. (1987) Immunologically Mediated Growth Depression in Chicks: Influence of Feed Intake, Corticosterone, and Interleukin-1. The Journal of Nutrition, 117, 1629-1639.

[63] Schmitz, J., Owyang, A., Oldham, E., Song, Y., Murphy, E., Mcclanahan, T.K., Zurawski, G., Moshrefi, M., Qin, J., Li, X., Gorman, D.M., Bazan, J.F. and Kastelein, R.A. (2005) Il-33, an Interleukin-1-Like Cytokine That Signals via the il-1 Receptor-Related Protein st2 and Induces T Helper Type 2-Associated Cytokines. Immunity, 23, 479-490.

[64] Pain, S.J., Revell, D.K. and James, P.J. (2003) Effect of Sulphur Amino Acids on Epithelial Immunity and Parasite Susceptibility. Asia Pacific Journal of Clinical Nutrition, 12, S58.

[65] Dinarello, C.A. (2013) Overview of the Interleukin-1 Family of Ligands and Receptors. Seminars in Immunology, 25, 389-393.

[66] Brownborg, H.M., Rakoczy, S.G., Wonderlich, J.A., Rojanathammanee, L., Kopchick, J.J., Armstrong, V. and Raasakka, D. (2014) Growth Hormone Signaling Is Necessary for Lifespan Extension by Dietary Methionine. Aging Cell, 13, 1019-1027. https://doi.org/10.1111/acel.12269

[67] Mulinacci, F., Poirier, E., Capelle, M.A., Gurny, R. and Arvinte, T. (2013) Influence of Methionine Oxidation on the Aggregation of Recombinant Human Growth Hormone. European Journal of Pharmaceutics and Biopharmaceutics, 85, 42-52.

[68] Wu, G., Bazer, F.W., Wallace, J.M. and Spencer, T.E. (2006) Board-Invited Review: Intrauterine Growth Retardation: Implications for the Animal Sciences. Journal of Animal Science, 84, 2316-2337. https://doi.org/10.2527/jas.2006-156

[69] Ugarte, N., Ladouce, R., Radjei, S., Gareil, M., Friguet, B. and Petropoulos, I. (2013) Proteome Alteration in Oxidative Stress-Sensitive Methionine Sulfoxide Reductase-Silenced hek293 Cells. Free Radical Biology and Medicine, 65, 1023-1036.

[70] Sreekumar, P.G., Kannan, R., Yaung, J., Spee, C.K., Ryan, S.J. and Hinton, D.R. (2005) Protection from Oxidative Stress by Methionine Sulfoxide Reductases in rpe Cells. Biochemical and Biophysical Research Communications, 334, 245-253.

[71] Kantorow, M. and Weissbach, H. (2004) Methionine Sulfoxide Reductase a Is Important for Lens Cell Viability and Resistance to Oxidative Stress. Proceedings of the National Academy of Sciences of the United States of America, 101, 9654-9659. https://doi.org/10.1073/pnas.0403532101

[72] Wood, J.M., Decker, H., Hartmann, H., Chavan, B., Rokos, H., Spencer, J.D., Hasse, S., Thornton, M.J., Shalbaf, M., Paus, R. and Schallreuter, K.U. (2009) Senile Hair Graying: h2o2-Mediated Oxidative Stress Affects Human Hair Color by Blunting Methionine Sulfoxide Repair. The FASEB Journal, 23, 2065-2075.

https://doi.org/10.1096/fj.08-125435

[73] Luo, S. and Levine, R.L. (2008) Methionine in Proteins Defends against Oxidative 
Stress. The FASEB Journal, 23, 464-472. https://doi.org/10.1096/fj.08-118414

[74] Cellarier, E., Durando, X., Vasson, M.P., Farges, M.C., Demiden, A., Maurizis, J.C., Madelmont, J.C. and Chollet, P. (2003) Methionine Dependency and Cancer Treatment. Cancer Treatment Reviews, 29, 489-499.

[75] Cavuoto, P. and Fenech, M.F. (2012) A Review of Methionine Dependency and the Role of Methionine Restriction in Cancer Growth Control and Life-Span Extension. Cancer Treatment Reviews, 38, 726-736.

[76] Hoffman, R.M. (1985) Altered Methionine Metabolism Andtransmethylation in Cancer. Anticancer Research, 5, 1-30.

[77] Miller, R.A., Buehner, G., Chang, Y., Harper, J.M., Sigler, R. and Smith-Wheelock, M. (2005) Methionine-Deficient Diet Extends Mouselifespan, Slows Immune and Lens Aging, Alters Glucose, T4, IGF-I and Insulinlevels, and Increases Hepatocyte MIF Levels and Stress Resistance. Aging Cell, 4, 119-125. https://doi.org/10.1111/j.1474-9726.2005.00152.x

[78] Bolander-Gouaille, C. and Bottiglieri, T. (2007) Homocysteine: Related Vitamins and Neuropsychiatric Disorders. 2nd Edition, Springer-Verlag, Paris.

https://doi.org/10.1007/978-2-287-69375-5

[79] Dunlevy, L.P., Burren, K.A., Mills, K., Chitty, L.S., Copp, A.J. and Greene, N.D. (2006) Integrity of the Methylation Cycle Is Essential for Mammalian Neural Tube Closure. Birth Defects Research Part A: Clinical \& Molecular Teratology, 76, 544552. https://doi.org/10.1002/bdra.20286

[80] Zingg, J.M. and Jones, P.A. (1997) Genetic and Epigenetic Aspects of DNA Methylation Ongenome Expression, Evolution, Mutation and Carcinogenesis. Carcinogenesis, 18, 869-882. https://doi.org/10.1093/carcin/18.5.869

[81] Wallwork, J.C. and Duerre, J.A. (1985) Effect of Zinc Deficiency on Methionine Metabolism, Methylationreactions and Protein Synthesis in Isolated Perfused Rat Liver. The Journal of Nutrition, 115, 252-262.

[82] Baker, D.H. and Boebel, K.P. (1980) Utilization of the d- and l-Isomers of Methionine and Methionine Hydroxy Analogue as Determined by Chick Bioassay. The Journal of Nutrition, 110, 959-964.

[83] Noll, S.L., Waibel, P.E., Cook, R.D. and Witmer, J.A. (1984) Biopotency of Methionine Sources for Young Turkeys. Poultry Science, 63, 2458-2470. https://doi.org/10.3382/ps.0632458

[84] Baker, D.H. (1994) Utilization of Precursors for L-Amino Acids. In: D’Mello, J.P.F., Ed., Amino Acids in Farm Animal Nutrition, CAB International, Wallingford, 3762.

[85] Hasegawa, H., Shinohara, Y., Akahane, K. and Hashimoto, T. (2005) Direct Detection and Evaluation of Conversion of d-Methionine into l-Methionine in Rats by Stable Isotope Methodology. The Journal of Nutrition, 135, 2001-2005.

[86] Aldrich, G. (2007) DL-Methionine: Several Vital Functions. http://www.Petfoodindustry.com/ViewArticle.Aspx?Id=18526

[87] Xie, W., Zhao, H. and Cheng, J. (2010) Advances in Clinical Application of s-Adenosyl-1-Methionine. World Chinese Journal of Digestology, 32, 391-395. https://doi.org/10.11569/wcjd.v18.i33.3553

[88] Prescott, L.F., Sutherland, G.R., Park, J., Smith, I.J. and Proudfoot, A.T. (1976) Cysteamine, Methionine, and Penicillamine in the Treatment of Paracetamol Poisoning. The Lancet, 2, 109-113.

[89] Nandi, D., Patra, R.C. and Swarup, D. (2005) Effect of Cysteine, Methionine, Ascorbic Acid and Thiamine on Arsenic-Induced Oxidative Stress and Biochemical 
Alterations in Rats. Toxicology, 211, 26-35.

[90] Lertratanangkoon, K. and Scimeca, J.M. (1993) Prevention of Bromobenzene Toxicity by n-Acetylmethionine: Correlation between Toxicity and the Impairment in o- and s-Methylation of Bromothiocatechols. Toxicology \& Applied Pharmacology, 122, 191-199. https://doi.org/10.1006/taap.1993.1187

[91] Nicastri, P.L., Diaferia, A., Tartagni, M., Loizzi, P. and Fanelli, M. (1998) A Randomised Placebo-Controlled Trial of Ursodeoxycholic Acid and s-Adenosylmethionine in the Treatment of Intrahepatic Cholestasis of Pregnancy. An International Journal of Obstetrics \& Gynaecology, 105, 1205-1207. https://doi.org/10.1111/j.1471-0528.1998.tb09976.x

[92] Nieto, N. and Cederbaum, A.I. (2005) S-Adenosylmethionine Blocks Collagen i Production by Preventing Transforming Growth Factor-Beta Induction of the COL1A2 Promoter. Journal of Biological Chemistry, 280, 30963-30974. https://doi.org/10.1074/jbc.M503569200

[93] Lintner, K. and Chamberlin, C.M. (2013) Cosmetic Composition Comprising Hydroxymethionine and 3-Aminopropanesulfonic Acid. U.S. Patent No. 8,377,663. U.S. Patent and Trademark Office, Washington DC.

[94] Greene, R.C., Su, C.H. and Holloway, C.T. (1970) S-Adenosylmethionine Synthetase Deficient Mutants of Escherichia Coli k-12 with Impaired Control of Methionine Biosynthesis. Biochemical \& Biophysical Research Communications, 38, 1120 1126.

[95] Cuq, J.L., Besancon, P., Chartier, L. and Cheftel, C. (1978) Oxidation of Methionine Residues of Food Proteins and Nutritional Availability of Protein-Bound Methionine Sulphoxide. Food Chemistry, 3, 85-102.

[96] Stabb, J. (2002) Changing Preferences: Conventional Photography versus the Digital Image in the Documentation and Communication of Built Form. Chemistry- $A$ European Journal, 21, 485-492.

\section{Scientific Research Publishing}

Submit or recommend next manuscript to SCIRP and we will provide best service for you:

Accepting pre-submission inquiries through Email, Facebook, LinkedIn, Twitter, etc. A wide selection of journals (inclusive of 9 subjects, more than 200 journals)

Providing 24-hour high-quality service

User-friendly online submission system

Fair and swift peer-review system

Efficient typesetting and proofreading procedure

Display of the result of downloads and visits, as well as the number of cited articles

Maximum dissemination of your research work

Submit your manuscript at: http://papersubmission.scirp.org/

Or contact health@scirp.org 